\title{
The Views of Class Teachers on Acquisition of Entrepreneurship Ability
}

\author{
Soner Aladă \\ Correspondence: Soner Aladağ, Assist. Prof. Dr., Adnan Menderes University, Faculty of Education, Department of \\ Primary Education, Turkey.
}

Received: June 4, 2017

Accepted: June 29, 2017

Online Published: July 9, 2017

doi:10.11114/jets.v5i8.2457

URL: https://doi.org/10.11114/jets.v5i8.2457

\begin{abstract}
Aim of this study is to determine the views of class teachers on the acquisition of entrepreneurship abilities. With being a qualitative research, adopted approach is phenomenology. Study group was determined by a suitable sampling method. The study group included eight classroom teachers working in primary schools in Aydın. The data of the study were collected using a semi-structured interview technique based on qualitative research. Content analysis method was used in the analysis of the data. At the end of the study, four main themes were reached. These themes; entrepreneurship abilities in teaching programs, methods and techniques in transferring entrepreneurship abilities, difficulties in transferring entrepreneurship abilities, and suggestions for transferring entrepreneurship abilities. All of the class teachers who participated in the study have the opinion that entrepreneurship abilities must be included in the curriculum. Class teachers who expressed their views on the adequacy of teaching programs in terms of entrepreneurship abilities found their teaching programs inadequate. Teachers who participated in the study stated that they use the drama method most in their entrepreneurship abilities. Class teachers explained difficulties they encounter with problems with the program, student, parent, and school conditions. One of the main difficulties faced by teachers in the transfer of abilities is program-related problems. With the light of the data obtained, class teachers load the problems they experience into factors outside of themselves. They do not evaluate themselves in terms of desire, knowledge and skill.
\end{abstract}

Keywords: class teachers, entrepreneurship, entrepreneurship education, ability

\section{Introduction}

The world economy is changing and developing rapidly. It is an unavoidable necessity for countries to have a competitive structure in this economic development. The most important part of this competitiveness is entrepreneurial individuals. That is, individuals who have the courage to innovate, take risks, have a high self-confidence, be creative, take initiative are needed.

The rapid change experienced in the world requires change in the field of education as it is in every area. In today's information age, the main aim of our educational system is to provide students with basic abilities that will lead them to knowledge rather than provide students with information directly. It is aimed to provide basic life abilities to the students with the new curriculums that have been implemented throughout the country in 2005-2006 academic year. One of the abilities which is targeted to be acquired is entrepreneurship abilities.

Entrepreneurship abilities have become so important that they are no longer discussed in today's society. Although the concept of entrepreneurship is mostly discussed in the economic dimension in our literature, the educational dimension which is effective in acquiring this skill should not be ignored. As information production or information has an important structure today entrepreneurship is becoming more and more important.

The rapid developments in science and technology is changing the structures of the societies, they have also increased the economic value and importance of the entrepreneurship and entrepreneurs who are a part of it. As a reflection of this, entrepreneurship based on individual and individual ability has become important and human intellectual productivity ability has gained importance (Arslan, 2002). In this context, the entrepreneur is the one who constantly monitors the economy to find new jobs, capital and operates other resources (labor, raw materials, tools, production facilities, etc.) he is a real or legal person / person who leads an objective for the realization of this innovative activity, establishes and operates an organizational structure for this purpose, and this whole process is defined as entrepreneurship (Tanrisever, 2004). 
Entrepreneurship is a process that causes changes in the economic system, with the innovations brought about by individuals who respond to economic opportunities or create economic opportunities (Muzyka, Koning and Churchill, 1994; cited from Yllmaz and Sünbül, 2009). In another definition, entrepreneurship is defined as the process of creating value, establishing a new business from profit-oriented business, or creating a new business or creating a new good or service (Bird, 1989; cited from Çetinkaya, Bozkurt, 2011). In other words, entrepreneurship is the creation of new and unknown information, including the opportunity to see existing opportunities or create opportunities (Hisrich and Peters, 2002). Özdevecioğlu and Cingöz (2009) also define the concept of entrepreneurship as "a process in which some opportunities are sought to create value and different resources are brought together to benefit from these opportunities".

According to Pan and Akay (2015), entrepreneurship is a kind of behavioral feature, and this characteristic may not exist in every individual. Because behaviors are composed of various factors and are shaped being affected by these factors. Individual differences and social influences are also the main factors which influence entrepreneurship.

When looking at the common characteristics of entrepreneurial people and the meaning of the concept of entrepreneurship entrepreneurial people seem to have some common characteristics. According to Norma (1993), entrepreneurial characteristics are as follows. The entrepreneur is more motivated, more self-confident, more independent, more responsible, more creative, more flexible in thinking and acting, more initiative, more determined, better at evaluating opportunities, better at coping with failure, better at using resources, better at using time, better at working with groups, better attacking risks, better at reasoning, better at problem solving, better at communication, better at being a mediator, better at planning, better at decision making, better at knowledge.

Ağca and Yörük (2006) state that the accepted qualities that characterize entrepreneurship are the need for success, independence, risk taking, self-confidence, innovation, creativity, perseverance, flexibility and certain experience and abilities.

The goal of entrepreneurship training is to ensure that a person has the awareness and awareness of a number of hidden features that are aimed at entrepreneurship potential. To prevent those who have entrepreneurial qualities from doing the wrong things and to realize use of resources more efficiently (Çetinkaya, Bozkurt and Alparslan, 2013). Curth (2011) emphasizes that entrepreneurship education has three main purposes. These are:

- To equip individuals with the abilities, knowledge and attitudes necessary to take responsibility for their learning career and their lives. These are; Motivation, awareness, individual responsibility etc.

- Increasing individual awareness of the world, economy and change in general. This goal is to gain some knowledge (eg about the economy and the business world) and some attitudes (to develop positive attitudes towards entrepreneurship and change)

- Support and develop entrepreneurial and innovative behavior. For this abilities (eg creativity and innovation, working together) knowledge (starting and sustaining a job) and attitudes (a tendency to take initiative) are required.

Patır and Karahan (2010) emphasize that entrepreneurship education is more important need in providing students with more assertive, self-confidence and problem-solving abilities, that's why it is very important to determine the entrepreneurship abilities of students and to provide data that can be used during the re-screening of entrepreneurship education.

Abilities, knowledge and attitudes related to entrepreneurship can be developed by education and training as well as other activities (leisure time activities, sports activities, family environment, etc.) There is no consensus on which knowledge abilities and attitudes are best developed. However, the fundamental idea of entrepreneurship education is that education plays an important role in gaining these knowledge and abilities (Curth, 2011).

It must be paid attention to the appropriateness of the teaching methods used by the educational sciences in order to provide entrepreneurship to the people (Çetinkaya, Bozkurt and Alparslan, 2013). The best entrepreneurship training depends on the pedagogies used in the classroom. Gibb (2005) stated that entrepreneurship education requires methods in which students gain experience and feel the inner general feeling. He also stated that the environments in which a learning environment for a good entrepreneurship environment is controlled and where students feel secure in the learning process and also mentioned as environments where flexible interactive interdisciplinary knowledge is required for the learning process and faults are considered as part of the learning process.

Seikkula-Leino (2007) used the methods and techniques that could be used in entrepreneurship training in the following way: Collaborative learning, problem-based learning, group and peer work, project work, learning by doing, creative drama, structured diaries, mini-companies, research trips, field trips and guest speaker.

In a study with teachers in Finland where entrepreneurship training was included in the program and this training could 
be a good example, teachers have indicated that they use the following methods in entrepreneurship training (Ikävalko, Ruskovaara and Seikkula, 2009).

-Class discussion: Talking about entrepreneurship is the most common method. Almost all of the teachers stated that they use this method.

- To ensure that students take part in projects in the school: Two thirds of the teachers have done this kind of work. Teachers have shown that this method requires extra resources as the reason for not always being applied.

Educational institutions could be considered as entrepreneurial, the classes could be considered entrepreneurial places, teachers could be considered as entrepreneurial individuals. This means that educational institutions that train teachers of the future should formulate new paradigms and pedagogical models because they can equip future teachers with the abilities and attitudes necessary for entrepreneurship education with this way (Curth, 2011). Entrepreneurship abilities are among the abilities that are intended to be taught to students in all courses in primary school programs implemented in 2005-2006. For example, students on entrepreneurship abilities in the Social Studies program.

- Recognizing occupations and surrounding workplaces

- Recognition of well-known and successful entrepreneurs

- Discover the roles people play as consumers and employees in the economy

- Understanding the important role of education on their future

- Getting the basic concepts of economy

- Understand the challenges that entrepreneurship faces

- It aims to provide innovative ideas and design products (MEB, 2005).

Entrepreneurship can be given in many subjects in primary education. Class teachers have a very important position to train entrepreneurial individuals with the possibility of linking these issues with entrepreneurial issues, as they teach many topics. In this study, the opinions of the class teachers were used in order to determine the effectiveness of the entrepreneurship abilities of the students targeted to be acquired in the teaching programs and the effectiveness of this skill.

The aim of this study is to reveal the opinions of the class teachers on the targeted entrepreneurship abilities to be acquired in the teaching programs. Within the scope of this aim the following questions were sought:

1. What are the thoughts of the class teachers on the place where teaching programs are gaining entrepreneurial abilities?

2. What are the views of class teachers on the methods and techniques used in the transfer of entrepreneurship abilities?

3. What sort of problems is faced by class teachers in gaining entrepreneurial abilities?

4. What are the suggestions of class teachers to ensure that entrepreneurship abilities are adequately provided to students?

\section{Method}

In this study, which aims to determine the viewpoints of the class teachers' acquisition of entrepreneurship abilities, a qualitative research design, phenomenology design was used. Phenomenology focuses on what we are aware of, but we do not have an in-depth and detailed understanding. Phenomena can emerge in various forms such as events, experiences, perceptions, orientations, concepts and situations in the world we live in. However, this acquaintance does not mean that we fully understand the facts. Phenomenology constitutes a suitable research ground for studies that are not completely unfamiliar to us, but also aim to investigate events that we can not fully understand (Y1ldirım and Şimşek, 2006).

\subsection{Study Group}

The study group of this research consists of 8 class teachers, 4 of them are female and 4 of them are male. The study group of the research was determined by appropriate sampling method. The appropriate sampling method is expressed as a collection of data from a sample that the researcher can easily reach (Büyüköztürk et al, 2014). 
Table 1. Personal Features of Participants

\begin{tabular}{lllll}
\hline Participants & Gender & $\begin{array}{l}\text { Occupational } \\
\text { Work period }\end{array}$ & Instituition & $\begin{array}{l}\text { Situation of participating a } \\
\text { program related to the } \\
\text { abilities }\end{array}$ \\
\hline Teacher 1 & female & 4 & MEB* & no \\
Teacher 2 & female & 5 & MEB & no \\
Teacher 3 & male & 6 & MEB & no \\
Teacher 4 & male & 12 & MEB & no \\
Teacher 5 & female & 27 & MEB & no \\
Teacher 6 & male & 8 & MEB & no \\
Teacher 7 & male & 29 & MEB & no \\
Teacher 8 & female & 30 & MEB & no \\
\hline
\end{tabular}

* Ministry of National Education

\subsection{Data Collection Tool}

Semi-structured interviews with participants were conducted to reveal the views of class teachers on gaining entrepreneurship abilities. Interviewing is a very powerful method used to reveal the experiences, feelings and perceptions of people's point of view (Yıldırım and Şimşek, 2006). The views and recommendations of two field experts have been taken into consideration in order to strengthen the validity of the study of interview questions. In the direction of the experts' proposals, four questions were asked to the class teachers who were asked, rearranged and participated in the research as a result of these arrangements.

\subsection{Data Collection Process}

Interviewing with participants were based on volunteerism. Before the interview, it was stated that the content of the work done by the participant will be used for scientific purposes and will contribute to the field. In addition, it is mentioned that the names will be kept strictly confidential in order to reach objective and reliable results. Participants were asked to identify themselves and interviews started and the questions were asked in a row and the interviews were completed in the appropriate environment. All of the interviews were carried out face to face, recorded with voice recorder and field notes were kept. Then, the data obtained from the class teachers were written into interview forms through the Office program. Interviews were completed in 25-30 minutes on average.

\subsection{Data Analysis}

In phenomenological researches data analysis aims at revealing the meanings and lives. In this direction, 'content analysis' method was used in the analysis in order to examine the data of this study in depth. The way in which the data is analyzed is as follows:

(1) Coding of data

(2) Finding themes

(3) Organizing codes and themes

(4) Interpretation and identification of findings (Yıldırım and Şimşek, 2006).

At the beginning of the interview analysis, the interview forms were numbered according to the participants' order (S 1, M1). When the data were coded, the two researchers who performed the work independently encoded on the same data set. Then the consistency between the codes of each of the researchers was checked and the coherence value between the codes was found to be 0.81 . Data were reread according to the codes reached a consensus. The codes obtained from the opinions of the class teachers were classified according to their similarity and closeness in terms of meaning then themes and sub themes were reached. The obtained data are directly supported and interpreted by the quotations where necessary. Four main themes have been reached in this study. Reached main themes are: Entrepreneurship abilities in teaching programs, methods and techniques for transferring entrepreneurship abilities, difficulties in transferring entrepreneurship abilities, and suggestions for transferring entrepreneurship abilities.

In order to increase the validity and reliability of the study, the process of data analysis was tried to be transferred in a clear and understandable way. In addition to this, the percentage of correspondence between the codes that the researches reached independently was examined. "Reliability $=$ Consensus / (Consensus + visibility) x 100 " formula was used to calculate the percentage of compliance. When evaluating the compatibility of the codes, marking was done in the form of Consensus and Visibility, and the main codes were determined. 


\section{Findings}

\subsection{Findings Related to the First Sub Aim}

In this part, the opinions of class teachers about where teaching programs are supplying entrepreneurship abilities are gathered under the theme of 'Entrepreneurship Ability in Teaching Programs'. This main theme covers 4 sub-themes. The themes and encodings for this sub-theme are given in Table 2.

Table 2. Theme: Entrepreneurship Abilities in Teaching Programs

\begin{tabular}{|ll|}
\hline SUB THEMES & CODINGS \\
\hline In terms of the necessity of taking place in programs & $\begin{array}{l}\text { Being one of the most important characteristics } \\
\text { that must be found in the programs, being one of } \\
\text { the most important characteristics that must be } \\
\text { found in the ages, being one of the conditions of } \\
\text { educating talented individuals, being a society in } \\
\text { progress, being a prosperous society from an } \\
\text { economic point of view, having entrepreneurial } \\
\text { abilities, raising individuals, not falling in } \\
\text { difficult situations, To be ready for life, to } \\
\text { develop the individual, to achieve life-long } \\
\text { success, to take a more active role in school and } \\
\text { social life, to supply entrepreneurship abilities. }\end{array}$ \\
\hline In terms of the adequacy of the programs & $\begin{array}{l}\text { Inadequate, curriculum-intensive, primary } \\
\text { school curriculums that do not leave the } \\
\text { necessary time, are ineffective, do not take place } \\
\text { in the curriculum enough, must be sensed and } \\
\text { acquired in a planned way, are in the } \\
\text { background, cannot be seen in the curriculum }\end{array}$ \\
\hline In terms of the age level given & $\begin{array}{l}\text { In the first steps of the educational life are more } \\
\text { appropriate for younger, early-age, secondary } \\
\text { and high school students }\end{array}$ \\
\hline
\end{tabular}

In terms of the necessity of taking place in programs

All of the class teachers participating in the study find it very positive that entrepreneurship abilities are included in the programs in order to be able to raise individuals with appropriate qualifications. Class teachers have advocated that entrepreneurship abilities should take place in programs:

"I think it is necessary for the entrepreneurship skill to take part in the program. Because it is one of the most important features that must be found in our age" (T1,F).

“...absolutely necessary. I think it is one of the requirements of raising talented individuals"(T2,F).

"Yes, it is necessary because we think that in our age we have to grow up with entrepreneurial individuals in order to make our society progress and to be an economically prosperous society" (T3,M).

“Absolutely necessary. A person reaches success through entrepreneurship throughout his life"(T7,M).

"Entrepreneurship abilities need to take part in the program in order for students to take a more active role in their school and social life" (T8,M).

In terms of the adequacy of the programs

According to the data in Table 2, the class teachers find all of the teaching programs which are important structures in acquiring entrepreneurship abilities, inadequate. Teacher coded as T8,M stated that as in other curricula, I think primary school curricula are insufficient in terms of entrepreneurship.T3,M expressed that "I think entrepreneurial skill is part of the program as a backward-looking skill. We do not see entrepreneurship fully in books and programs". T7,M stated that "...inadequate. It should be developed in accordance with the level and age".

In terms of the age level given

A few of the class teachers who participated in the study think that entrepreneurship abilities should start at the first stage of education life. Teacher coded as T1,F said that "this feature can also be acquired if given at an early age It 
should take place in the programs in this way this skill can be supplied".

Only one of these teachers did not agree that entrepreneurship abilities should be given in the first steps of elementary school. T5,F said that "I think it will be more useful for middle school and high school students".

\section{In Terms Of Hidden Programs}

According to the data obtained ; The number of teachers who think that the hidden program is effective in acquiring Entrepreneurship skill is very few. The views of teachers with this view are as follows:

"Criticism, disregarding what it says, and redemption will reduce entrepreneurship in children .... I frequently make students go out on top of the desks, and say loudly 'I am Ali, I am going to 2nd grade. I want to be a doctor when I grow up. 'At first, the student who gets very sick and shy starts to gain more self confidence later on" (T4,M).

"I am trying to increase the confidence of students" $(T 7, M)$.

\subsection{Findings Related to the Second Sub Aim}

In this part, findings obtained about the methods, techniques and activities that are effective in transferring Entrepreneurship ability according to class teachers are presented. Themes and codings are given in Table 3.

Table 3. Theme: Methods and Techniques for Transforming Entrepreneurship Abilities

\begin{tabular}{|ll|}
\hline Sub themes & Codings \\
\hline & $\begin{array}{l}\text { Student-centered education, life-learning by doing, question and answer, } \\
\text { discussion method, project assignments, discussion method, group work, } \\
\text { In terms of methods and techniques } \\
\text { animation, drama, story building, observation, research study path, brainstorming, } \\
\text { drama, cooperative learning, active learning, Events including observation and } \\
\text { examination, chess, music, folklores, portfolio. }\end{array}$ \\
\hline
\end{tabular}

In terms of methods and techniques used

Teachers participating in the study use method-techniques such as drama, learning by living by active learning, discussing and cooperative learning, making story less, observing, sightseeing, studying, chess, folk dances, music and portfolio in acquisition of entrepreneurship abilities.

Teacher coded as T6,M stated that I use animation, drama, story creation methods. Activities including sightseeing and observation can also be done.

Teacher coded as T1,F said that "student-centered teaching method I think is an effective way to improve entrepreneurship in students".

T8,M said "I think that activities such as chess, folk dances, music can improve entrepreneurship abilities positively".

T3 E "I use more questions-answer and discussion methods. I have student discussions on specific topics. We are also trying to support this skill with project assignments".

\subsection{Findings Related to the Third Sub Aim}

In this part, findings related to the problems that class teachers have experienced while transferring Entrepreneurship abilities are given. The themes and codes for this purpose are given in Table 4.

Table 4. Theme: Difficulties in Transforming Entrepreneurship Abilities

\begin{tabular}{|ll|}
\hline Subthemes & Codings \\
\hline In terms of programs & $\begin{array}{l}\text { Inadequate sample activities, not being included among other topics, time, } \\
\text { procedure, intensity of the program, curriculum anxiety, inadequacy of } \\
\text { books, }\end{array}$ \\
\hline Interms of student & $\begin{array}{l}\text { Uninterested, unable to produce ideas,take subjects in different ways, } \\
\text { behaving in a shy way, taking students to the center, low profile, } \\
\text { self-confidence, unable to catch up with class level, negativity. }\end{array}$ \\
\hline In terms of environmental factors & Environment, inadequacy of parent support, school conditions \\
\hline
\end{tabular}

Class teachers who participated in the study have mostly explained the difficulties they experienced in transferring entrepreneurship abilities, mostly by their students, and rarely by environmental factors (family, social activity and school facilities).

\section{In terms of programs}

Teacher codede as T1,F stated that there is not much time to study,

It is possible to skip acquisition of abilities. We can not find enough sample activities that can be done for this skill. 
$\mathrm{T} 7, \mathrm{M}$, said that "I'm having problems with activity, time and procedure".

$\mathrm{T} 5, \mathrm{~F}$, said "Because of the program we must concentrate more intensely on lessons".

In terms of students

$\mathrm{T} 4, \mathrm{M}$ stated that "It takes a long time to raise the confidence of the student when the student shows a low profile at the end of his or her performance. Failing to make a big breakthrough makes it impossible to catch the class level".

$\mathrm{T} 3, \mathrm{M}$, "Students can stay indifferent, can not produce ideas about the subject, sometimes they can take them in different ways. They can be particularly shy".

In terms of environmental factors

$\mathrm{T} 8, \mathrm{M}$, "acquisition of entrepreneurshipl abilities is also affected by the environment and school conditions as well as the inadequacy of parents' support. Teacher-parent dialogue is very inadequate".

\subsection{Findings Related to Fourth Sub-Aim}

In this part, the findings of the class teachers' suggestions are given in order to make students acquire entrepreneurship abilities. The themes and codes of this purpose are given in Table 5.

Table 5. Theme: Suggestions for Transferring Entrepreneurship

\begin{tabular}{|ll|}
\hline Sub themes & Codings \\
\hline In terms of programs & $\begin{array}{l}\text { Should take more places, there should be more activities, in-class } \\
\text { applications. }\end{array}$ \\
\hline & $\begin{array}{l}\text { Should be encouraging, creating opportunities, helping students taste the } \\
\text { sense of accomplishment, guiding, not being in negative criticism, not being } \\
\text { angry, teacher should give importance , teacher should be informed, } \\
\text { Teveloping the abilities, attitude of the teacher the skill, studying on the lack } \\
\text { of knowledge. }\end{array}$ \\
\hline
\end{tabular}

In terms of programs

T6,M "Entrepreneurship abilities should take place more in programs".

$\mathrm{T} 5$,F, "the programs should include more activities on entrepreneurship abilities".

$\mathrm{T} 5, \mathrm{~F}$ "Teachers should give importance to this skill ... this skill is given more in classroom practices".

In terms of teachers

$\mathrm{T} 2, \mathrm{~F}$, "It is necessary to encourage students. It is also necessary to create areas, opportunities that can show themselves. students must be guided by the taste of success".

$\mathrm{T} 4, \mathrm{M}$, "If the teacher wants to improve this skill, S/He should not be in negative criticism and should not be angry".

T3,M, "Teachers should be careful not to misuse them when choosing and using methods and techniques. At this stage, the teacher's view and attitude is highly influential".

T6,M, "Work on the lack of knowledge in teachers can be done".

\section{Conclusion, Discussion and Suggestions}

At the end of the study, 4 main themes were reached. Reached main themes; Entrepreneurship abilities in teaching programs, Methods and techniques in transferring entrepreneurial abilities, Difficulties in transferring entrepreneurial abilities, and Suggestions for transferring entrepreneurship abilities.

All of the class teachers who participated in the study have the opinion that entrepreneurship abilities must be included in the curriculum. Because one of the most important qualities that must be found in individuals is the entrepreneurship abilities. Individuals with entrepreneurship abilities are those who are able to evaluate the opportunities they are facing, do not give up, are social, are always in development, take an active role in their lives, are ready for life and have a lifelong success. It is inevitable to give this skill the necessary importance in order for our society to progress and to be a society that is economically prosperous.

At this stage, there is a great deal of responsibility for class teachers who transfer training programs and programs to determine entrepreneurship abilities and determine their future destiny. The class teachers participating in the study, although expressing indirectly some of the qualifications that should be found in the entrepreneurial individuals, seem not to have enough knowledge about this skill. Being an entrepreneur requires the following qualities (Commonwealth's Enterprise and Career Education Programme, 2002): 
- To produce and use creative ideas and processes

- To see, create, evaluate and turn the opportunities into opportunities

- Take the initiative

- Being responsible

- To see, assess and overcome risks

- Opening the information and the proposal

- Accessing and evaluating resources

- Good use of time and energy

- Looking for information

- Taking lessons from hackers

- Work efficiently with others

- Communication and influence

- Flexibility to change

- Cope with stress and tension

- Solving the conflict in a constructive and interviewing environment

- Seeing and evaluating your own and others' performance.

In general, the entrepreneur is the one who constantly monitors the economy to find new jobs, capital and operates other resources (labor, raw materials, tools, production facilities, etc.) he is a real or legal person / person who leads an objective for the realization of this innovative activity, establishes and operates an organizational structure for this purpose, and this whole process is defined as entrepreneurship (Tanrisever, 2004).

The class teachers who expressed their views on the adequacy of teaching programs in terms of entrepreneurship abilities found their teaching programs inadequate. They pointed out that entrepreneurship abilities were backwards in the program's intensity, and that they did not come across clearly in books and programs.

During interviews, it was concluded that class teachers did not have enough knowledge of entrepreneurship abilities in curricula and programs. In addition, several of the class teachers who participated in the study expressed that the introduction of entrepreneurship abilities at early ages from the first stages of the educational life would be more beneficial in gaining this achievement, while only one teacher indicated that the qualities of entrepreneurship abilities were more appropriate for middle and high school students.

Although our age requires entrepreneurial individuals, this skill must take place in teaching programs in accordance with the level of students in primary school. This is very important for development of a child.

If attributes covered by entrepreneurship abilities such as taking risks, seeing friends as customers, marketing the product, having economic knowledge, determining job opportunities, pursuing the economy, competitiveness, individualization, self-assurance, independence, flexible workforce production, career development cannot be transferred to the students in the age of the planned and the level appropriate, we will leave selfish, racing, ambitious, capitalist and collecting individuals who do not evaluate the person with human values. What is evident is that class teachers who prepare children should act rather well and planned rather than haphazard.

Two of the class teachers who participated in the study indicated that they had taken self-reliance steps and benefit from hidden programs to develop entrepreneurship abilities in their students. It enables young people to adapt to change in society, work, employment, careers and societies, and even help them initiate this change (Commonwealth's Enterpriseand Career Education Programme, 2002).

Class teachers who participated in the study do not use sightseeing and observation activities which are very effective in gaining entrepreneurship abilities. However, the hidden program is quite convenient for children to gain entrepreneurial abilities in terms of including activities such as sightseeing, observation, studying of work environments and exhibitions, company trips. During these activities, children will be able to see the environments in which the employers and employees are present, to get information from the persons concerned, and to discover their popular career areas, to identify their own career, to examine their research activities, to create new ideas and to make new designs.

Teachers who participated in the study stated that they use the drama method most in their entrepreneurship abilities. They generally use techniques which make students active, learning by living, learning based on discussion and cooperation, they rarely use techniques such as story building, observation, sightseeing, examination, chess, folk dances, 
music, portfolio Seikkula-Leino (2007) used the methods and techniques that could be used in entrepreneurship training as: collaborative learning, problem-based learning, group and peer study, project work, learning by doing, creative drama, structured diaries, mini-companies, and guest speaker.

In a study conducted with teachers in Finland, teachers indicated that they use the following methods for entrepreneurship training (Ikävalko, Ruskovaara and Seikkula, 2009).

- Classroom discussion: Talking about entrepreneurship is the most common method. Almost all of the teachers stated that they use this method.

- Ensure that students take part in school projects: Two thirds of the teachers have done this kind of work. Teachers have shown that this method cannot be applied as extra resource requirements are needed.

- Organizing study visits to companies: Half of the teachers said that they organized a study visit to the companies.

- Group work, peer-work, collaborative learning: Using learning by doing and using real-world simulations and creative problem-solving techniques are among the methods used by teachers.

These results support the results of Hytti and O'Gorman (2004). Hytti and O'Gorman (2004) examined 50 educational institutions at different levels in Austria, Ireland and the United Kingdom and concluded that they used the following methods, respectively, according to their frequency of use in entrepreneurship education: Traditional teaching methods, business simulations and workshop studies, guidance, setting up a new business, study visits, games, and competitions and applied teaching.

According to the obtained data, it can not be said that the class teachers have been aware and effective in applying some methods and strategies about how the entrepreneurship abilities of students will be gained. This seems to be due to the difficulties they have experienced in defining entrepreneurship abilities. Class teachers explained the difficulties they face with problems with the program, student, parent, and school conditions. According to the teachers who participated in the study, during the training of the students, students can not produce an opinion about the topic, sometimes they can take the subjects in different directions. One of the teachers implied that these situations are because of the low level of the students. Many of the teachers have pointed out that the students are shy and that this prevents the development of entrepreneurship abilities.

Gibb (2005) suggested that the influence of learning environments for students is very important; the environments in which a learning environment of a good entrepreneurship environment is controlled and where students feel secure in their learning process are also mentioned as environments where flexible interdisciplinary knowledge is required for the learning process and faults are considered as part of the learning process.

At the same time, environmental and school conditions, inadequacy of parent support, and inadequacy of teacher-parent dialogue are among the limitations of class teachers.

At the beginning of the difficulties faced by teachers in the transfer of abilities are program-related problems. The class teachers who participated in the study pointed out that the entrepreneurial abilities among the subjects to be worked out were not enough for the training of the curriculum due to the difficulty of completing the curriculum and the lack of the sample activities that could be applied while gaining entrepreneurship abilities.

In the study they conducted, Gömleksiz, Kan, Biçer and Yetkinler (2010) pointed out that there were some deficiencies in the students, programs textbooks and schools in terms of getting the entrepreneurship abilities. Suggestions have been made about activating students, using different materials, eliminating deficiencies, educating families on this issue and making more activities.

In the study of Güven (2010), by including more acquisitions of entrepreneurship characteristics in the program, students can be supported to be entrepreneurial individuals, also for the students to gain the entrepreneurship characteristics, the teachers who are working in primary education should be given more activities for the achievement of the lesson about entrepreneurship in the curriculum.

One of the teacher said that "the program is so intense that we have to concentrate on the lessons". As seen, the class teacher who participated in the study is not aware of the fact that the abilities involved in the program are included in the course content. He thinks this skill is taken as a separate lesson.

Entrepreneurship should not be a separate topic or lesson in primary education. Entrepreneurship can be given in many subjects in primary education. Class teachers are very important to train entrepreneurial individuals with the opportunity to connect these issues with entrepreneurship topics, as they teach many topics (Commonwealth's Enterprise and Career Education Programme, 2002).

With the light of the data obtained, class teachers load the problems they experience into factors outside themselves. 
They do not evaluate themselves in terms of desire, knowledge and skill. Teachers seem to accept their deficiencies in the suggestions they have offered to develop this skill. Class teachers' suggested solutions for strengthening the abilities:

- Teachers should give importance to this skill,

- Teachers should be informed about the importance of the skill before they develop this skill,

- Teachers should be careful not to misuse the methods and techniques when selecting and using them,

- Works on the knowledge deficiencies in teachers should be done,

- Teachers should be a good guide for entrepreneurship to students,

- Entrepreneurial abilities should take more place in programs,

- The programs should include more activities on entrepreneurship abilities.

In addition to the suggestions of the teachers participating in the research, the following suggestions can be made based on the results. It can reduce most of the difficulties faced by class teachers on abilities training through various programs such as seminars, symposium, conferences or in-service training.

In order for class teachers to be able to educate individuals who are suitable for the ages in their professional life, effective learning environments for putting and implementing practical abilities courses in undergraduate programs should be presented during undergraduate education.

It is important for students to meet with rich learning environments where formal or informal activities that contribute to the development of entrepreneurial abilities such as museum research and development exhibitions, sightseeing and observation activities can be carried out.

\section{References}

Ağca, V., \& Yörük, D. (2006). Differences between independent entrepreneurship and intrapreneurship: a conceptual framework. Afyon Kocatepe University Journal of Economics and Administrative Sciences, 2, 155-173.

Arslan, K. (2002). Professional preferences of university students and enterprise education. Doğuş University Journal, 6 , $1-11$.

Büyüköztürk, Ş., Kılıç, Ç. E., Akgün, Ö. E., Karadeniz, Ş., \& Demirel, F. (2014). Scientific Research Methods. Ankara: Pegem Academy Publishing.

Commonwealth's Enterprise and Career Education Programme (2002). Enterprise education in primary schools. Australia. ISBN: 1863664645.

Curth, A. (2011). Mapping of teachers' preparation for entrepreneurship education (Ed. Daniela Ulicna). Final Report, Framework Contract No EAC 19/06, Dg Education and Culture, J 30258322.

Çetinkaya, B. Ö. (2011). Enterprise education in the world and in Turkey: suggestions from successful entrepreneurs and academics. Ankara: Detay Publishing.

Çetinkaya, B. Ö., \& Alparslan, A. M. (2013). Characteristics of entrepreneurial people and enterprise education: views of entrepreneurs and students. Journal of Enterprise and Development, 8(1), 2013.

Gibb, A. (2005). The future of entrepreneurship education-determining the basis for coherent policy and practice?. The Dynamics of learningentrepreneurship in a cross-cultural university context. Eds. P. Kyrö \& C. Carrier. University of Tampere, Research Centre for Vocational and Professional Education.

Gömleksiz, M. N., Kan, A. Ü., Biçer, S., \& Yetkinler, A. ( 2010 ). Teacher views on the efficiency of primary education second grade social sciences education program with regard to acquisition of entrepreneurship ability. $I^{\text {st }}$ National Education Programs and Teaching Congress. 13-15 May 2010. Balıkesir.

Güven, S. (2010). An evaluation of social studies teaching programs in terms of entrepreneurship qualities. NWSA-Education Sciences, 1C0113, 5(1), 49-57.

Hisrich, R. D., \& Peters, M. P. (2002). Enterpreneurship. USA: Mc.Graw-HillIrwin.

Hytti, U., \& O'Gorman, C. (2004). What is "enterprise education"? an analysis of the objectives and methods of enterprise education programmes in four european countries. Education+Training, 46(1), 11-23. https://doi.org/10.1108/00400910410518188

Ikävalko, M., Ruskovaara, E., \& Seikkula-Leino, J. (2009). Rediscovering teacher's role in entrepreneurship education. Paper presented at the EFMD conference, Barcelona, February, 26-27. 
MEB. (2005). Primary education lesson teaching program and guidebook for the 4th and 5th grades. Ankara: State Books Office.

Norma, I. (1993). Enterprise education in primaryschools: A survey in primary schools: A survey in two northern LEAs. Education+Training, 35(4), 22-30.

Özdevecioğlu, M., \& Cingöz, A. (2009). Sosyal girişimcilik ve sosyal girişimciler: teorik çerçeve. Erciyes Üniversitesi Iktisadi ve Idari Bilimler Dergisi, 32, 81-95.

Pan, V., \& L., A. C. (2015). An evaluation of the entrepreneurship level of faculty of education students through several variables. NWSA-Education Sciences, 1C0637, 10(2), 125-138.

Patır, S., \& Karahan, M. (2010). A field research for determining the nature of enterprise education and university students' entrepreneurship profile. Business and Economics Research Journal, 1(2), 27-44.

Seikkula-Leino, J. (2007). Curriculum reform and entrepreneurship education. Opetusministeriön Julkaisuja, 2007:28, Yliopistopaino, Helsinki.

Tanrisever, N. H. (2004). Policies for promoting entrepreneurship in the EU and the coordination between the policies in Turkey and the EU practices. Unpublished Dissertation, Ankara: Secretariat General for European Union Affairs.

Yıldırım, A., \& Şimşek, H. (2006). Sosyal bilimlerde nitel araştırma yöntemleri, Ankara: Seçkin Yayıncılık.

Y1lmaz, E., \& Sünbül, A., (2009). Development of entrepreneurship scale for university students. Selçuk University Journal of Social Sciences, 21,195-203.

\section{Copyrights}

Copyright for this article is retained by the author(s), with first publication rights granted to the journal.

This is an open-access article distributed under the terms and conditions of the Creative Commons Attribution license which permits unrestricted use, distribution, and reproduction in any medium, provided the original work is properly cited. 